\title{
REVISION OF THE GENUS NEOSCOLECITHRIX (COPEPODA, CALANOIDA) AND DESCRIPTION OF N. CAETANOI, SP. N., COLLECTED OFF BRAZIL
}

MARIA PALOMA JIMENEZ ALVAREZ

\section{ABSTRACT}

The genus Neoscolecithrix is redefined and its situation in the family is discussed.

The division of the species of this genus into two groups, "kehleri" and "farrani", is proposed, based on marked differences in the type of the rostrum, in the mandible's gnathobase, in the maxilla 2 and in the legs, especially the fifth leg.

Xanthocalanus watersae Grice (1972) is considered a species of Neoscolecithrix. The female and the male of N. caetanoi $s p$. n., collected off the Brazilian coast at $900 \mathrm{~m}$ depth, are described.

\section{INTRODUCTION}

The genus Neoscolecithrix was established by Canu (1896) with the description of $N$. koehleri. The author then suggested including Scolecithrix minor Brady, 1883 (= Scolecithrix roemeri Mrázek, 1902, in Bradford, 1973) in this genus. But Sars (1903) elected this species as the type-species of the genus Scolecithricella, considering marked differences relatively to the genus Scolecithrix.

In 1905 Farran described a new genus and species Oothrix bidentata based on a juvenile specimen. T. Scott (1909) considered this species as well as Scolecithrix koehleri Giesbrecht 1898, synonymous with N. koehleri Canu, and as valid the genus of the latter. But the name Oothrix continued in use by several authors posteriorly.

The second species of the genus, $N$. farrani, was described by Smirnov (1935). This species was redescribed in 1972 by Fosshagen and in the same year Prygunkova described a male from the White Sea. Fosshagen (op. cit.) considered a third species, Oothrix borealis Wiborg (1949), as synonymous with N. farrani. Grice (1972) described the third species of Neoscolecithrix with the name Ooothrix magna. He also described Xanthocalanus watersae, which Campaner (1978) suggested should be included in the genus Neoscolecithrix. N. watersae is considered the fourth species of the genus.

The Copepodite V of Neoscolecithrix sp., described by Bradford (1973), is most probably the copepodite of $N$. magna (Grice, 1972), especially because of the aspect of the fifth pair of legs.

Thus, the following species are considered as belonging to the genus Neoscolecithrix: N. koehleri Canu, 1896, N. farrani Smirnov, 1935, N. magna (Grice, 1972), N. watersae (Grice, 1972), and N. caetanoi, sp. n.

The Neoscolecithrix species live in deep waters near to or on the bottom and probably have an important role in the ecosystem of those regions (Shih \& Stallard, 1982).

This is the first time that the genus Neoscolecithrix is found in Brazilian waters.

\section{MATERIAL}

The two adult females and the male were collected on the $7^{\text {th }}$ September 1970 at 5.30 A.M., just above the bottom, $900 \mathrm{~m}$ deep, off Brazil, at 21037'S$40^{\circ} 03^{\prime} \mathrm{W}$. 
The mesh aperture of the net used was $0.67 \mathrm{~mm}$. The net was adapted to a special MBT dredge devised by Dr. Plínio Soares Moreira of the Instituto Oceanográfico of the University of São Paulo.

The holotype and the adult male (alotype) are deposited in the Zoology Museum of the University of São Paulo, numbered 5253 and 5254 respectively. The other adult female is deposited in the Copepod Museum of the Department of Zoology of the Instituto de Biociências of the University of São Paulo, numbered 185 .

\section{Genus Neoscolecithrix Canu, 1896}

Synon.: Oothrix Farran, 1905, p. 42, 43, pl. X and XI.

Neoscolecithrix A. Scott, 1909, p. 125, 126.

Redefinition:

Female: Cephalosome fused to the first segment of metasome; fourth and fifth segments of metasome usually fused, with two projections postero-laterally. Bifid rostrum, which may have filaments. Urosome four-segmented; the anal segment may be very reduced. Posterior margins of urosomal segments serrated. Antenna 1: 24-25 joints and some sensory appendages. Antenna 2: exopod longer than endopod. Maxilla 1: second internal lobe with 3 setae and third with 4 setae. Maxilla: endopod with sensory setae ending "brushlike", and sensory worm-like setae without specialized endings. Maxilliped: $1^{\text {st }}$ basipod with sensory seta. Swimming appendages: $1^{\text {st }}$ to $4^{\text {th }}$ pairs with $1: 2: 3: 3$ joints respectively. $5^{\text {th }}$ pair of feet: symmetrical, three-jointed and without endopod.

Male: Cephalosome, antenna 1 and bucal appendages as in the female. Urosome 4-segmented, the first segment slightly asymmetrical and reduced; posterior margin of the three last segments serrated, $5^{\text {th }}$ pair of legs asymmetrical, one of them a little or much reduced in length; rudimentary endopod absent or present.

Type-species: N. koehleri Canu, 1896.

Neoscolecithrix caetanoi, sp. n.

Description of the female: (Figs. 1 to 21).

Prosome (Figs. 1 and 2) almost elliptical in dorsal view; $2^{\text {nd }}$ and $3^{\text {rd }}$ segments of metasome fused. Rostrum (Fig. 3) wide and protruding, ending in two short points. $5^{\text {th }}$ metasomal segment (Fig. 4) with 2 postero-lateral projections on each side.

Proportional lengths of cephalosome and segments of metasome (including its lateral projections) $=64.8: 13.3: 7.8: 5.5: 8.6$. Urosome (Fig. 5) with 4 segments, the last very reduced and not visible dorsally, posterior margins of first three segments with teeth of irregular sizes giving the margin a saw-like aspect (Fig. 6). Proportion between prosome: urosome lengths: 82:18. Proportion between the urosome segments and furcal rami: 47.3:18.2:12.7:21.8= 100.

Antenna 1 of both specimens damaged. Antenna 2 (Fig. 7): exopod longer than endopod.

Mandible palp (Fig. 8) and gnathobase (Fig. 9) well developed. Masticatory margin of gnathobase with spiniform seta, ornamented with thick setules, the by 3 long teeth and 6 smaller teeth, several teeth probably trifid, and finally one distal tooth peculiarly-shaped (Fig. 10).

Maxilla 1 (Fig. 11) with 9 setae on first external lobe; 10 setae on exopod; 13 setae on $1^{\text {st }}$ internal lobe; 3 setae on $2^{\text {nd }}$ internal lobe; 4 setae on $3^{\text {rd }}$ internal lobe; 5 setae on basipod and 9 setae on endopod.

Maxilla 2 (Fig. 12) with 4 plumose and fine setae on $1^{\text {st }}$ lobe, and, on each of the $2^{\text {nd }}$ to $5^{\text {th }}$ lobes, 1 thicker seta with spinules and 2 plumose thinner setae. Endopod with 2 types of sensory setae: 4 are fine and long, with a distal button; and the 3 terminal are thicker. 
Maxilliped (Figs. 13 and 14): $1^{\text {st }}$ basipod with 10 setae, 3 wider and probably sensory; $2^{\text {nd }}$ basipod with 3 setae and a group of numerous fine, short setules on its internal face; endopod with $5,4,4$, and 3 setae from the $1^{\text {st }}$ to the $5^{\text {th }}$ joint.

Legs: 3 first pairs (Figs, 15, 17 and 19 respectively) with spines (Figs. 16,18 and 20 respectively from the $1^{\text {st }}$ to the $3^{\text {rd }}$ pair) on the $2^{\text {nd }}$ basipod, near to the articulation with the endopod. These spines are different in num. ber and form in each pair; in the fourth pair they were absent. The endopod and exopod of the $2^{\text {nd }}, 3^{\text {rd }}$ and $4^{\text {th }}$ pair of legs were damaged.

$5^{\text {th }}$ pair of legs (Fig. 21): 3-jointed, with long joints, the last with 4 spines ( 2 terminal, 1 of them not articulated, 1 external-lateral and 1 internallateral). All spines ornamented with short and thick setae.

Description of the Male: (Figs. 23 to 26).

Length along the dorsal mid-line $-3.40 \mathrm{~mm}$. Prosome (Figs. 23 and 24) long, broadly triangular in front. Cephalosome fused to $1^{\text {st }}$ metasome segment; $4^{\text {th }}$ and $5^{\text {th }}$ metasomal segments ending in two postero-lateral protrusions at each side, the right ones longer than the left ones in dorsal view.

Rostrum (Figs. 25 and 26) bifid.

Urosome (Fig. 28) with 4 segments, the genital asymmetrical; the posterior margins of the last three segments serrated. Proportion prosome-urosome length $=79: 21$, and proportion between lengths of cephalosome and metasome segments (including laterai protrusions) $=67.8: 10.7: 8.3: 4 \cdot 9: 8.3=100$. Proportion between lengths of urosome segments and furcal rami respectively $=18.4: 26.3: 18.4: 15.8: 21.1=100$.

Antennules - incomplete (Fig. 27).

Bucal appendages (Figs. 29, 30, 31, 32 and 33) structured as in female. $1^{\text {st }}$ pair of legs (Fig. 34) similar to female's, but having 4 spines (Fig. 35) on $2^{\text {nd }}$ basipod. $2^{\text {nd }}, 3^{\text {rd }}$ and $4^{\text {th }}$ legs damaged.

$5^{\text {th }}$ pair of legs: left ramus Fig. 36) 5-jointed, the most distal joint short with very fine setae. Right appendage three-jointed with 3 spines (1 external lateral, 2 terminal) on last joint. Only the left appendage has an endopod, very reduced and fused to the $2^{\text {nd }}$ exopod joint.

The species name was given in honour of my husband Caetano Carezzato Sobrinho.

\section{DISCUSSION}

Among the species of the genus, $N$. caetanoi is nearest to the species $N$. koehleri, differing from it in the following features: the number of setae on the maxilla 1, the type of the setae of the maxilla 2 lobes; the ornaments and length of the setae of the second basipod of the maxilliped; the size and number of the spines of the $2^{\text {nd }}$ basipod of the $2^{\text {nd }}$ pair of legs and the structure of the $5^{\text {th }}$ pair of legs in both sexes.

The structure of the $5^{\text {th }}$ legs of the females, although very similar in both species (Figs. 38 and 40) shows differences in the relative length and width of their joints and in the position of the lateral spines. In the males these appendages are very different, especially the strong reduction of the right appendage of $N$. caetanoi and the presence of spines on its last joint, while in $N$. koehleri the reduction occurs in the left appendage and there is no rudimentary endopod in this species.

The other female of $N$. caetanoi here studied is sexually mature, and is not so long as the holotype $(3.2 \mathrm{~mm}$ and $3.9 \mathrm{~mm}$ respectively), but both are equal in the other features, excepting in the aspect of the $5^{\text {th }}$ pair of legs (Figs. 21 and 22). This is a little different as to the position of the lateral spines of the third joint. It looks as if the fith pair of legs is not fully developed.

Something similar to that was observed by Sewell (1929) in Eucalanus subcrassus. But Vervoort (1941) when studying the morphology and biology of this same species did not confirm the possibility of sexual maturity occurring in copepodites V as Sewell (1929) had suggested. Vervoort (1941) observed a very incomplete development of the genital segment of the copepodites $\mathrm{V}$ 
of the species and concluded that the precocious sexual maturity would occur only in some exceptional cases. He added that the different degrees of dimorphism observed in the mature specimens resulted from different rhythms of growth. Sewell (1929) found that the rhythm of development diminishes considerably when maturation begins and is probably influenced by different conditions of the environment. Thus, the differences observed in the $5^{\text {th }}$ pair of legs in the two females of $N$. caetanoi suggest that the structure of these appendages may vary intraspecifically as a function of the growth rhythm, and that in this species the sexual maturity can precede the complete development of the secondary sexual characteristics.

The species of the genus Neoscolecithrix can be distributed into two groups considering the rostrum, the structure of the gnathobase of the mandible, the type of the setae of the $5^{\text {th }}$ lobe of the maxilla 2 and the morphology of the legs. Those of the "koehleri" group (Figs. 37 to 41) show a wide and long rostrum with two small points, with or without filaments; the masticatory blade of the mandible's gnathobase with one spiniform, thick seta armed with thick setules; one of the setae of the $5^{\text {th }}$ lobe of the maxilla 2 denticulated and long; the $2^{\text {nd }}$ basipod of the $1^{\text {st }}$ to $3^{\text {rd }}$ pairs of legs and the $1^{\text {st }}$ basipod of the $2^{\text {nd }}$ and $3^{\text {nd }}$ pairs with spines; the $5^{\text {th }}$ pair of $\mathrm{fe}$ male legs with long joints especially the $3^{\text {rd }}$, with 4 or 5 spines setuled; the $5^{\text {th }}$ pair of male legs very asymmetrical, with one of them very short and with or without a rudimentary endopod. To this group belong N. koehleri, N. magna and N. caetanoi.

The species of the other group "farrani" ( $N$. farrani and $N$. watersae, Figs. 42 a 45) show a short rostrum with two filaments, the masticatory blade of the mandible gnathobase with a setose fine seta, one of the setae of the $5^{\text {th }}$ maxilla 2 lobe thick and spiniform, the basipods of the $1^{\text {st }}$ to $4^{\text {th }}$ pairs of legs without spines, the $5^{\text {th }}$ pair of female legs with a globose second joint, the $3^{\text {rd }}$ joint with 3 to 4 setuled or naked spines, the males' $5^{\text {th }}$ pair of legs almost symmetrical in length, with a rudimentary endopod present in at least one of the appendages. The species of this group perhaps belong to another genus. Here the provisory separation of the species into two groups of Neoscolecithrix was preferred, until the situation of this genus in the family is more clearly defined.

The majority of the authors (Rose, 1933; Brodsky, 1967; Fosshagen, 1972 among others) included the genus in the Phaennidae. Bradford (1973), redefining the family, did not accept the above opinion, because the Neoscolecithrix species lack an important feature of the Phaennidae - the presence of spines on the endopods of the $2^{\text {nd }}$ to the $4^{\text {th }}$ pair of legs. But she did not suggest to which family the genus should belong.

Canu (1896) had already called attention to the similarity of the genera Scolecithrix, Xanthocalanus and Neoscolecithrix, proposing that the last one be intermediate between the other two.

Fosshagen (1972) remarked that $N$. farrani is an association of characteristics of several families, and concluded that a revision of the systematic position of this genus and of the families related to it was necessary. The different modes of life have influence on the morphology of the animals, according to the same author, and this may mask the phylogenetic relationships existing between the several copepod genera.

In this work, the genus discussed is included provisorily in the family Phaennidae taking Canu's (1896) and Fosshagen's (1972) opinions in consideration.

\section{ACKNOWLEDGMENTS}

I am grateful to Dr. Tagea K. S. Björnberg and Dr. A. F. Campaner for criticizing the manuscript and to Dr. Plínio Soares Moreira who collected the sample analyzed.

Additional financial support was provided by the Conselho Nacional de Desenvolvimento Científico e Tecnológico (Process number 105036-76). 


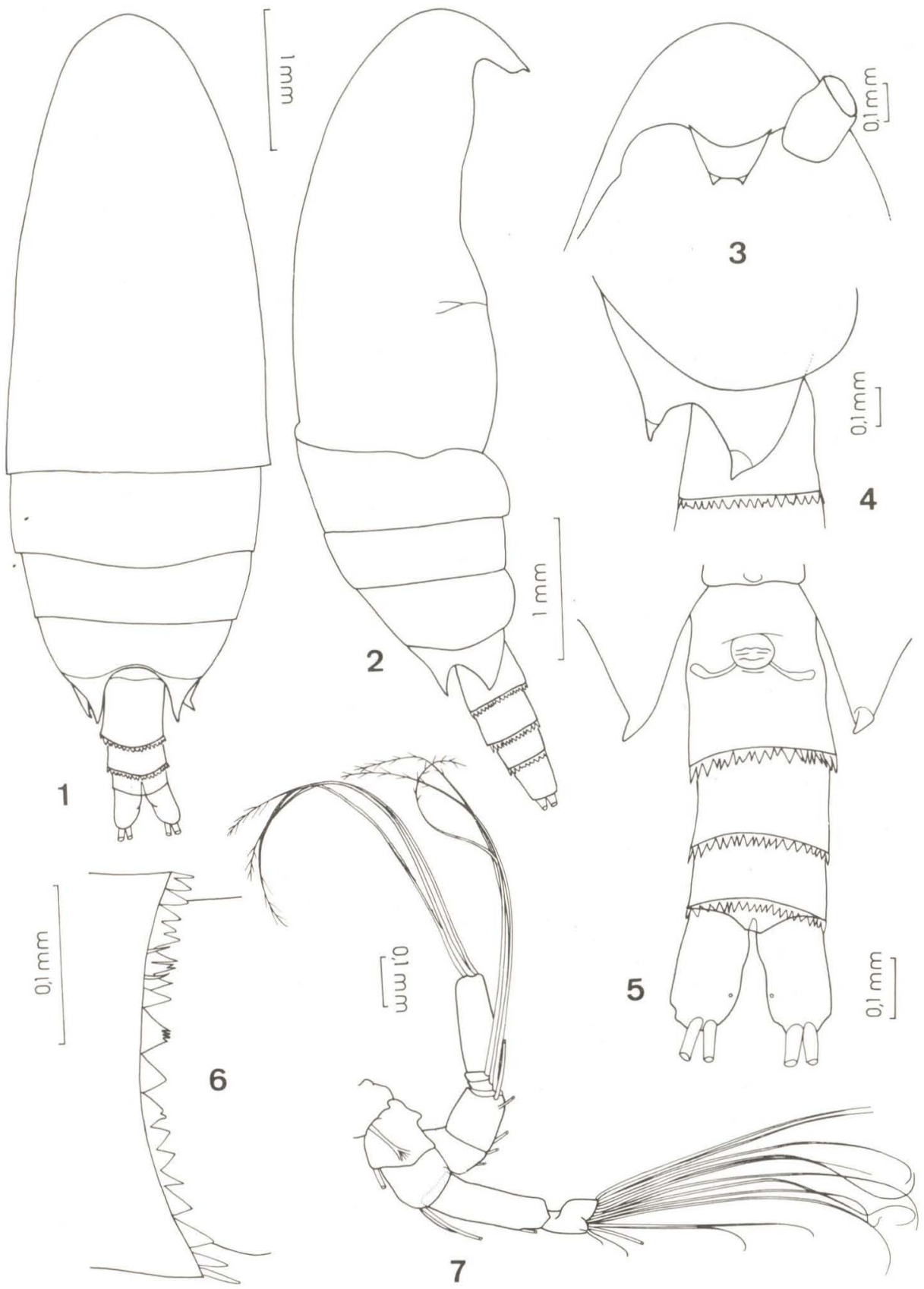

Neoscolecithrix caetanoi, sp. n. female: Fig. 1 - Dorsal view; Fig. 2 Lateral view; Fig. 3 - Rostrum, ventral view; Fig. $4-5^{\text {th }}$ metasomic segment, lateral; Fig. 5 - Urosome, ventral view; Fig. 6 - Posterior margin of the second urosome segment, dorsal view; Fig. 7 - Antenna 2. 


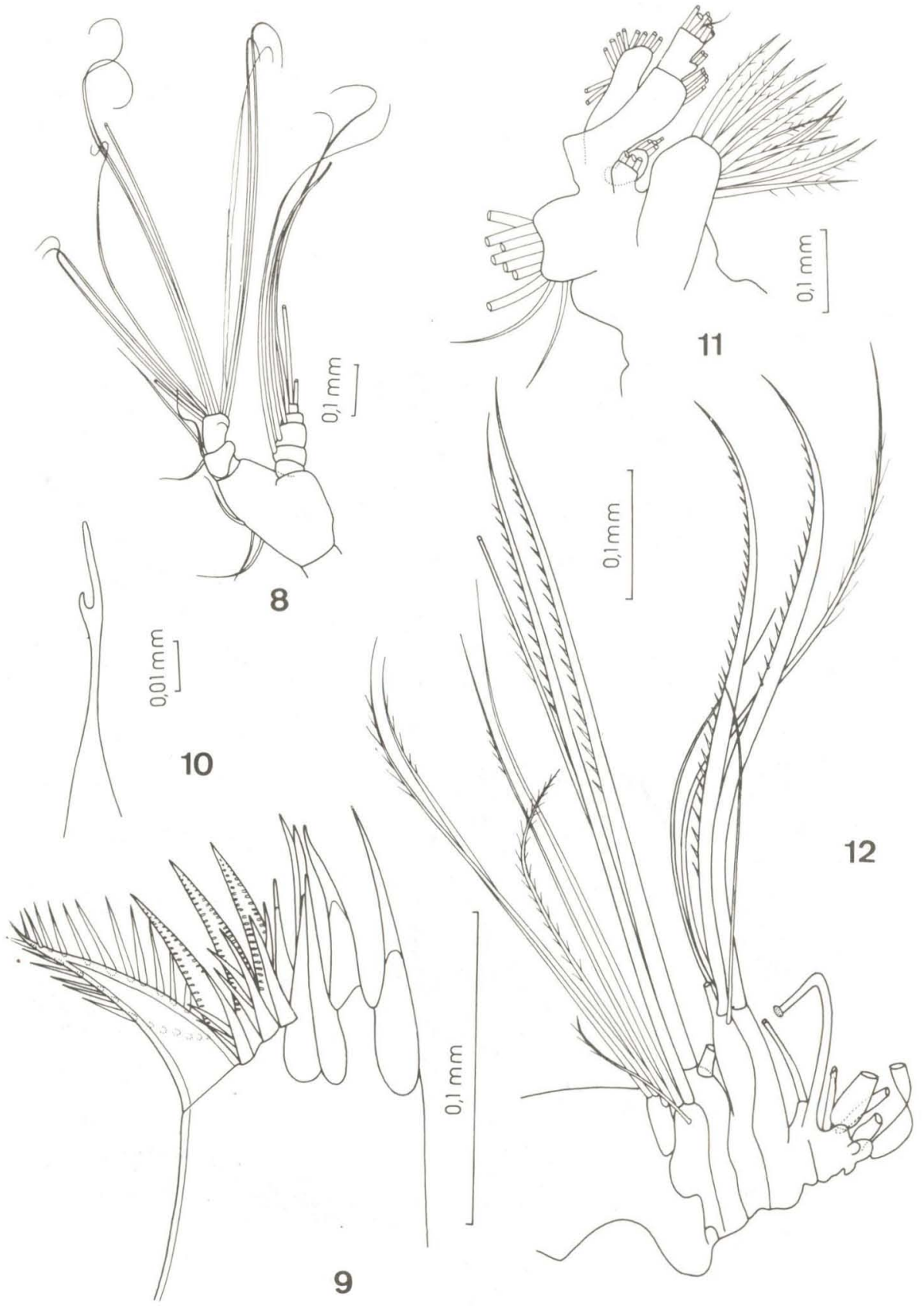

Neoscolecithrix caetanoi, sp. n. female: Fig. 8 - Mandible palp; Fig. 9 Mandible gnathobase; Fig. 10 - Distal tooth of the mandible gnathobase; Fig. 11 - Maxilla 1; Fig. 12 - Maxilla 2. 


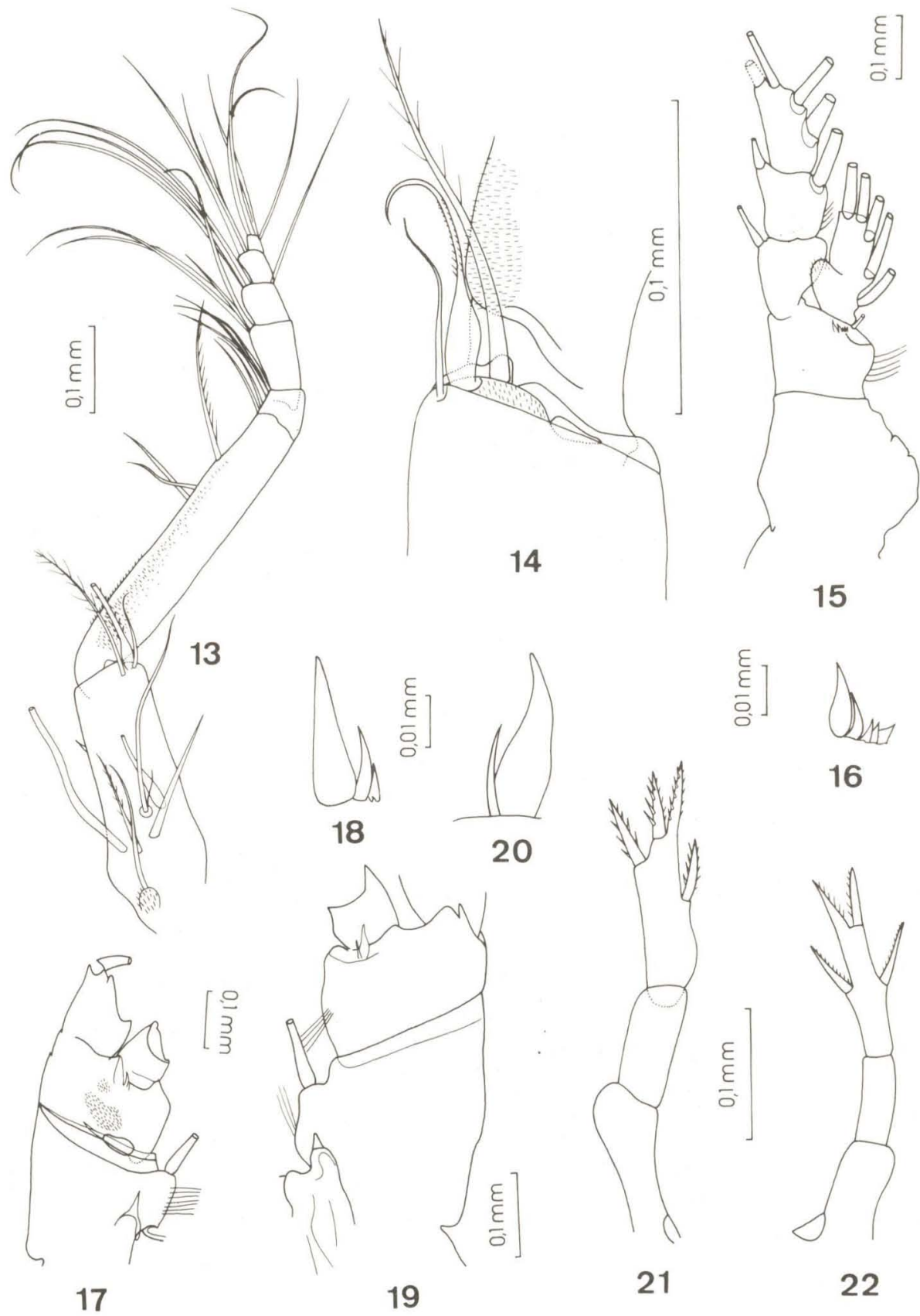

Neoscolecithrix caetanoi, sp. n. female: Fig. 13 - Maxilliped; Fig. 14 Distal region of the $1^{\text {st }}$ basipod of the maxilliped; Fig. $15-1^{\text {st }}$ leg; Fig. 16 - Spines of the $2^{\text {nd }}$ basipod of the $1^{\text {st }}$ leg; Fig. $17-2^{\text {nd }}$ leg; Fig. $18-$ Spines of the $2^{\text {nd }}$ basipod of the $2^{\text {nd }}$ leg; Fig. $19-3^{\text {rd }}$ leg; Fig. $20-$ Spines of the $2^{\text {nd }}$ basipod of the $3^{\text {rd }}$ leg; Fig. $21-5^{\text {th }}$ leg; Fig. $22-$ Fifth leg of the paratype. 

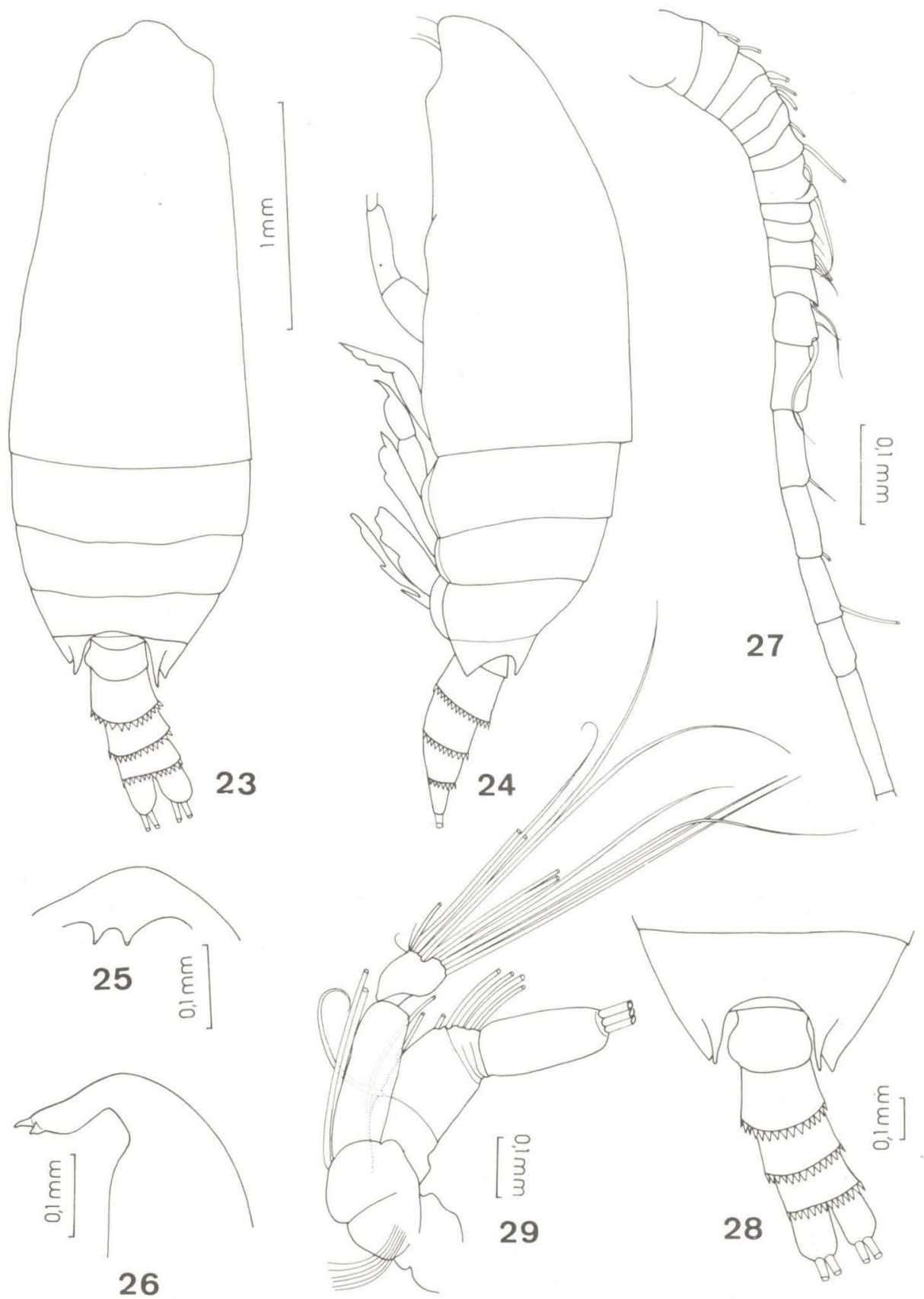

Neoscolecithrix caetanoi, sp. n. male: Fig. 23 - Dorsal view; Fig. 24 - Lateral view; Fig. 25 - Rostrum, ventral view; Fig. 26 - Rostrum, lateral view; Fig. 27 - Antenna 1; Fig. 28 - Urosome; Fig. 29 - Antenna 2. 


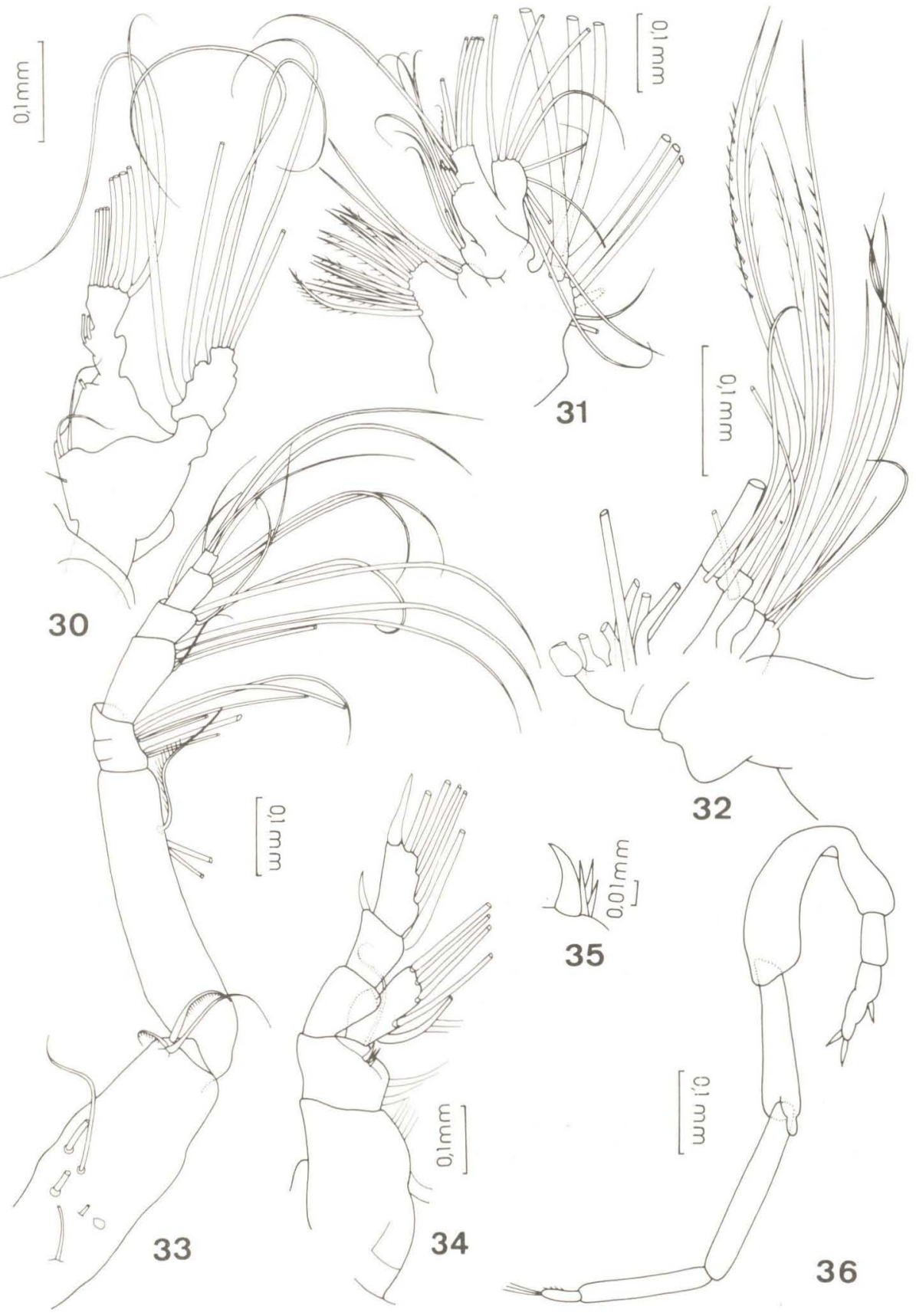

Neoscolecithrix caetanoi, sp. n. male: Fig. 30 - Mandible palp; Fig. 31 Maxilla 1; Fig. 32 - Maxilla 2; Fig. 33 - Maxilliped; Fig. 34 - 1st leg; Fig. 35 - Spines of the second basipod of the $1^{\text {st }}$ leg; Fig. 36 - Fifth leg. 

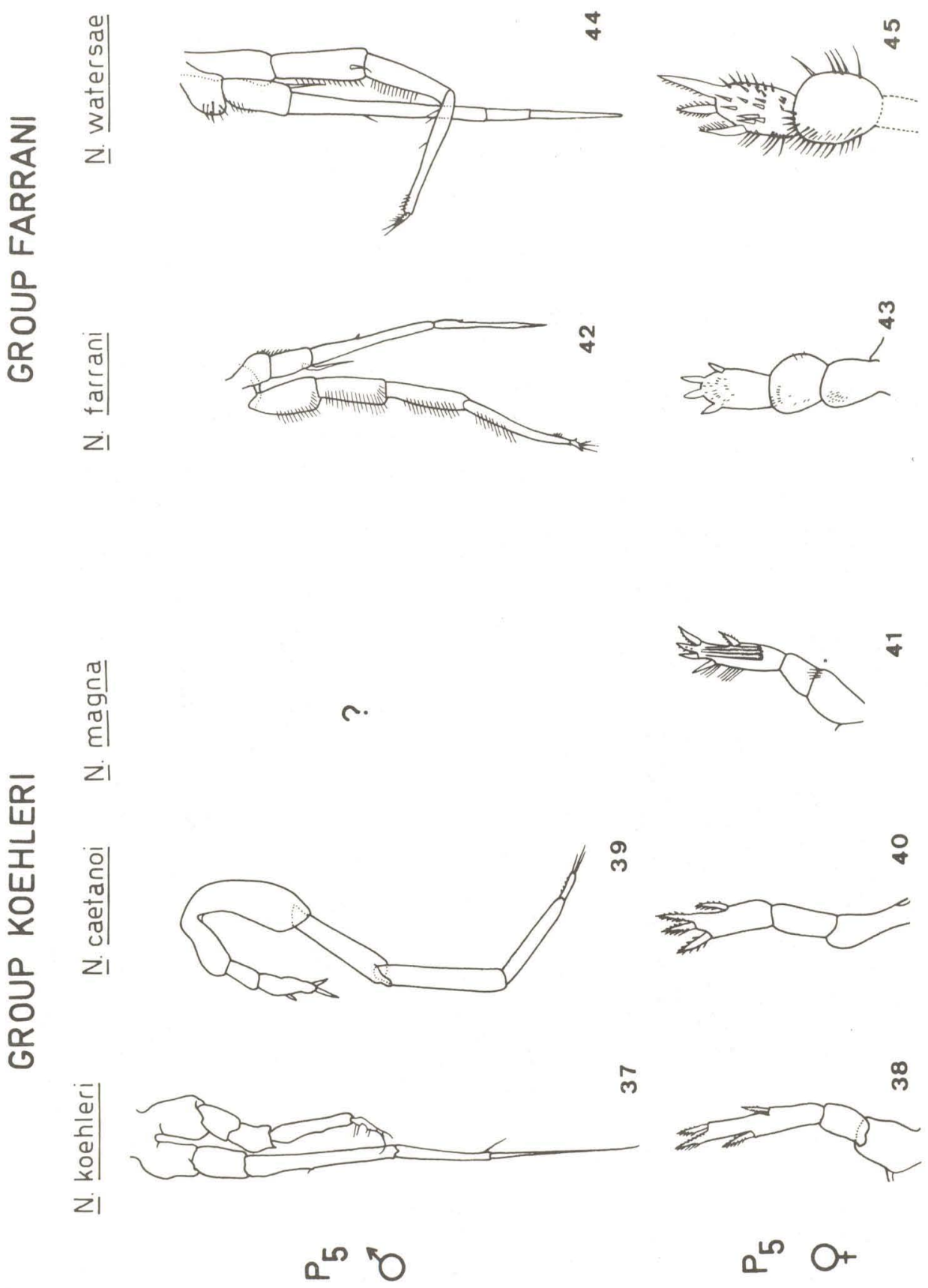

กิ

$\stackrel{\infty}{\infty}$

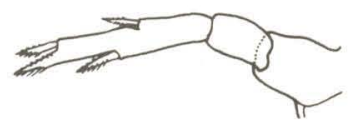

Groups of Neoscolecithrix species according to the fifth legs. Group "koehleri": N. koehleri after Canu (1896) fig. 37 and 38; N. caetanoi n. sp. Fig. 38 and 40; N. magna after Grice (1922) fig. 41. Group "farrani": N. farrani after Fosshagen (1972) fig. 42 and 43; N. watersae after Grice (1972) fig. 44 and 45. 


\section{REFERENCES}

Bradford, J., 1973. Revision of family and some generic definitions in the Phaennidae and Scolecithricidae (Copepoda: Calanoida). N. Z. Jl. mar. Freshw. Res. 7(1-2): 133-52.

Brady, G. S., 1883. Report on the Copepoda collected by H. M. S. "Challenger" during the years 1873-76. Rep. scient. Results Challenger Exped. Zool. 8: 1-142.

Brodsky, K. A., 1967. Distribution and length variation of individual Copepod species of the family Calanidae (Copepoda) in the Southern Hemisphere. Issled. Fauny Morei 4(12): 190-219.

Campaner, A. F., 1978. On some new planktobentic Aetideidae and Phaennidae (Copepoda, Calanoida) from the Brazilian continental shelf. II. Phaennidae. Ciênc. Cult. 30(8): 966-82.

Canu, E.. 1896. Copépodes. In. Koehler, R. ed. Résultats scientifiques de la campagne du: "Caudan" dans le Golfe de Gascogne. Paris, Masson et Cie. p. 421-37. (Annales de l'Université de Lyon, 26).

Farran, G. P., 1905. Report on the Copepoda of the Atlantic Slope Counties Mayo and Galway. Ann. Rep. Fish. 1902-3 (2), App. 2: 23-52, 13 pls.

Fosshagen, A., 1972. Neoscolecithrix farrani Smirnov (Copepoda Calanoida) from the North Norway. Astarte 5(1-2): 1-16.

Giesbrecht, W. \& Schmeil, O. 1898. Copepoda. I Gymnoplea. Berlin, Verlag von R. Friedlander und Sohn. 169 p. (Das Tierreich, 6 lief.)

Grice, G. D., 1972. The existence of a bottom-living calanoid copepod fauna in deep water with descriptions of five new species. Crustaceana 23(3): $219-42$.

Prygunkova, R. V., 1972. Description of unknown male Neoscolecithrix farrani Smirnov (Copepoda) from the White Sea. Trudy zool. Inst. Leningr. 52: 251-252.

Rose, M., 1933. Faune de France, v. 26: Copépodes pélagiques. Paris, Librairie de la Faculté des Sciences, 374 p.

Sars, G. O., 1903. An account of the Crustacea of Norway, with short descriptions and figures of all the species 5. Copepoda, Calanoida. Bergen, Bergen Museum. 171 p. 108 pls.

Scott, T., 1909. On some new and rare Entomostraca from the Scottish Seas. Ann. Mag. nat. Hist. ser. 8(3): 122-30 pls. II-IV.

Sewell, R. B. S., 1929. The Copepoda of Indian Seas. Ann. Mag. nat. Hist. ser. 8, 3: 122-30. pls. II-IV.

Shih, C. T. \& Stallard, N. 1982. Notes on two deep-water Calanoids (Aetidepsis rostrata and Neoscolecithrix farrani) from Lancaster Sound. Arctic 35(1): $56-60$.

Smirnov, S., 1935. Über die angebliche Oothrix bidentata Farran aus dem Weissen Meer. Zool. Anz. 109(9-10): 259-63.

Vervoort, W., 1941. Biological results of the Snellius expedition XV. The bathypelagic Copepoda Calanoida of the Snellius Expedition. Families Calanidae, Eucalanidae, Paracalanidae and Pseudocalanidae. Temminckia 8:1-115.

Wiborg, K. F., 1949. Ooothrix borealis sp. n. a bottom-dwelling Copepod from northern Norway (appendix). Fiskdir. Skr., Ser. Havunderkelsen 9(8): 26-7. 